UDK [159.944:614.253.1]:331.312.64

\title{
SLEEP AND FATIGUE IN HOSPITAL PHYSICIANS IN RELATION TO SHIFT WORK
}

\section{Vangelova K., Cekova I., Dimitrova I.}

\author{
National Center of Public Health and Analyses, Sofia, Bulgaria
}

Introduction. Sufficient and good quality sleep is crucial for shift workers because of its implications on performance and health. The aim of the study was to follow the effects of night shifts and overtime work on sleep and fatigue of hospital physicians in Bulgaria.

Methods. The study was cross-sectional and comprised 719 physicians, 429 female and 291 male, of average age (44.4 \pm 14.2 ) years from Sofia hospitals. Anonymous questionnaire survey included Karolinska Sleep Diary, demographic information, work place variables, working hours and shift system. The statistical analyses were carried out with SPSS.

Results. $26 \%$ of the physicians worked only in day shifts, $55 \%$ from 1 to 4 night shifts, and $28 \%$ more than 5 night shifts. Great deal of the physicians worked more than 40 hours weekly as follows: $38 \%$ worked $41-50$ hours per week, $27 \%-$ 51-60 hours and $14 \%>61$ hours. The quality of sleep, estimated by SQI was worse with the increase of the number of night shifts $(F=4.260, p=0.01)$ and sleep duration and insufficiency of sleep with increase of the hours worked weekly.

Discussion. Shift working with more night shifts monthly and overtime hours weekly contributed to impaired sleep in the studied group of physicians. The sleep impairment was more evident within the increase in the number of night shifts.

Key words: Night shifts, overtime, sleep quality index

\section{Introduction}

Some of the effects of night shift work are related to circadian disruption, sleep impairment and fatigue [1, 2], but also to higher risk of development of cardiovascular disease [4-6] and peptic ulcer [7]. Night work can also result in type 2 diabetes [8], rheumatoid arthritis [9], multiple sclerosis [10], cancer [11, 12] etc.

Night shift work is more prevalent in health care sector, especially in hospitals. Shortened or disturbed sleep is among the most common health-related effects of night shift work $[13,14]$. In a meta-analysis, based on 36 primary studies, Pilcher et al. [15] concluded that within rotating schedules night shifts resulted in the decrease of the length of sleep (mean 5.9 hours), while morning shifts had a moderate detrimental effect on sleep length (mean 6.6 hours). Insufficient sleep and poor sleep quality can contribute to fatigue, a critical issue also in relation to possible medical errors.

Working extended shifts (more than 8 hours per day), working overtime (more than 40 hours per week), and working both extended shifts and overtime can have adverse effects on sleep, alertness and worker's health. Extended shifts have been associated with higher risk of accidents, more psychosocial complaints, more cardiovascular symptoms, higher risk for development of hypertension [1, 16, 17]. Working overtime has also been associated with increased risk of making errors, poorer perceived health, adverse health effects, increased morbidity and mortality $[1,18,19]$.
The work of physicians is responsible and decisionrich in changing clinical environments with irregular working hours, often including night work and overtime.

The aim of the study was to study the effect of night shifts and overtime work on sleep and fatigue of hospital physicians in Bulgaria.

\section{Methods}

Study design. A cross-sectional survey was conducted which included 19 the largest hospitals (> 150 beds) in Sofia, Bulgaria, as a part of the study of risk factors for health in health care sector. The survey was anonymous, self-administered questionnaire was filled in by the physicians at their workplaces. 719 physicians took part in the study, 429 female and 291 male of the average age of $(44.4 \pm 14.2)$ years and the average length of service of $(19.2 \pm 14.0)$ years.

Data collection. The questionnaires included information about demographic, physical and behavioral characteristics as well as previous and current work schedules of the physicians. The information was collected on the current schedule with the options: only daily shifts, morning/afternoon shifts, rotating shifts or only night shifts. In the study, night shift was defined as hours worked between 24:00 and 08:00. Also, the information was collected on how many night shifts was worked per month: 0 nights per month, 1-2 nights per month, 3-4 nights per month, more than 5 nights per month. To assess the 
history of night work, respondents reported the number of years they worked in night shifts (including rotating and non-rotating night shifts). Also, the participants answered a question on overtime worked in the hospital and how often it happened, whether they had a second job, and taking in account the overtime and the second job how many hours on average they worked per week. The average hours worked per week were specified as follows: $21-40$ hours, $41-50$ hours, 51-60 hours and > 60 hours/week. In the analysis, we counted over 40 working hours per week for a long working week.

Sleep quality and fatigue. The participants completed a Karolinska Sleep Diary containing questions about «sleep duration», «sleep quality», «insufficiency of sleep», «fatigue in the morning after awakening», «ease of falling asleep», «waking up during sleep», «early awakening», and «sleep throughout». The questions were rated by a 5 -point scale $(1-$ bad sleep, 5 - no sleep problems). A sleep quality index SQI was formed and calculated from questions related to «sleep quality», «fatigue in the morning after awakening», «ease of falling asleep» and «sleep throughout». Fatigue was measured by a questionnaire, consisting of 9 questions concerning «the difficulty to rest after work», «the degree of fatigue at the end of the working day», «the feeling of rest after dinner», «the feeling of rest on the second day off», «the difficulty to concentrate after work», «communication problems after the end of the working day», «the need for more time to feel rested after work», «the desire for seclusion for about an hour after work», «the lack of willingness to do anything after work due to fatigue», «the inability for optimal work performance at the end of the day due to fatigue» and the fatigue was calculated summing the positive answers.

Data analysis. The data was introduced and processed with the SPSS 15.0 statistical package. ANOVA and Pearson correlation coefficient were used for statistical analyses, and the significance level was set at as $\mathrm{p}<0.05$.

\section{Results}

The study data showed that $26 \%$ of physicians worked only on day shifts, $10 \%$ worked on morning/ afternoon shifts and $64 \%$ worked on rotating shifts. The great part of physicians, working only on day shifts, have history of working rotating shifts with night work. $28 \%$ of physicians worked more than on 5 night shifts, $43 \%$ worked on 3 to 4 night shifts, $12 \%-1$ or 2 night shifts and $30 \%$ didn't have night shifts.

A great deal of physicians reported that they had overtime work (work after the end of the working time) as follows: $33 \%$ had rarely overtime work, $36 \%$ had overtime work $2-3$ times per week and $29 \%$ had overtime work every day. A part of physicians - $28 \%$ shared that they were working at the other work place. The additional work led to longer working hours per week. Only $21 \%$ of physicians shared that they worked 21-40 hours a week, while $38 \%$ worked 41-50 hours a week, $27 \%$ worked 51-60 hours a week and $14 \%$ worked over 61 hours a week.

Sleep duration did not differ by the type of the working time arrangements as the number of night shifts per month, but most of the sleep quality characteristics were significantly influenced by the number of night shifts per month, the most significantly the self-estimated insufficiency of sleep, fatigue in the morning after awakening, and sleep quality index (Table 1), followed by self-rated sleep throughout. The fatigue was higher in physicians, working on night shifts.

Sleep duration was shorter with working for more hours per week and the insufficiency of sleep increased (Table 2), but the quality of sleep did not seem to be influenced significantly. The fatigue increased significantly with the number of working hours per week.

Gender differences were found only for sleep duration $(F=15.240, p<0.001)$ and early awakening $(\mathrm{F}=7.166, \mathrm{p}<0.01)$. The female physicians slept more $(7.6 \pm 1.1)$ hours $)$ in comparison with males $(7.2 \pm 1.2)$ hours $)$, while the latter had more often early awakening.

The type of work time arrangements correlated negatively with insufficiency of sleep, fatigue in the morning after awakening and sleep quality index. Quality of sleep, insufficiency of sleep, fatigue in the morning after awakening and sleep quality index correlated negatively with number of night shifts per month, and insufficiency of sleep, fatigue in the morning after awakening, sleep duration and sleep quality index correlated negatively with the ratings of additional work after the end of the working time. The characteristics and insufficiency of sleep, fatigue in the morning after awakening and sleep duration correlated negatively with working hours per week (Table 3). 
Table 1

Quantity and quality of sleep ( $1=$ poor sleep, $5=$ no problems with sleep $)$ and fatigue ( 1 = low level of fatigue, $9=$ high level of fatigue) according to the number of night shifts per month for hospital physicians

\begin{tabular}{|l|c|c|c|c|c|}
\hline $\begin{array}{c}\text { Sleep characteristics and } \\
\text { fatigue/ number of night } \\
\text { shifts/month }\end{array}$ & $\begin{array}{c}\mathbf{0} \text { shifts } \\
(\mathbf{n}=\mathbf{2 2 6}) \\
\overline{\mathbf{x}} \pm \mathbf{S D}\end{array}$ & $\begin{array}{c}\mathbf{1 - 2} \text { shifts } \\
(\mathbf{n}=\mathbf{8 5}) \\
\overline{\mathbf{x}} \pm \mathbf{S D}\end{array}$ & $\begin{array}{c}\mathbf{3}-\mathbf{4} \text { shifts } \\
(\mathbf{n}=\mathbf{2 2 4}) \\
\overline{\mathbf{x}} \pm \mathbf{S D}\end{array}$ & $\begin{array}{c}\text { > 5 shifts } \\
(\mathbf{n}=\mathbf{1 9 8}) \\
\overline{\mathbf{x}} \pm \text { SD }\end{array}$ & F \\
\hline Sleep duration & $7.4 \pm 0.9$ & $7.5 \pm 1.2$ & $7.4 \pm 1.1$ & $7.4 \pm 1.4$ & $\mathrm{NS}$ \\
\hline Quality of sleep & $3.5 \pm 0.9$ & $3.5 \pm 1.0$ & $3.5 \pm 0.9$ & $3.3 \pm 0.9$ & $\mathrm{NS}$ \\
\hline Insufficiency of sleep & $2.7 \pm 1.3$ & $2.5 \pm 1.2$ & $2.4 \pm 1.1$ & $2.3 \pm 1.1$ & $4.451^{* *}$ \\
\hline $\begin{array}{l}\text { Fatigue in the morning } \\
\text { after awakening }\end{array}$ & $2.9 \pm 1.0$ & $2.6 \pm 0.9$ & $2.6 \pm 0.9$ & $2.6 \pm 0.9$ & $5.649^{* *}$ \\
\hline Ease of falling asleep & $3.6 \pm 1.0$ & $3.4 \pm 1.0$ & $3.5 \pm 1.0$ & $3.2 \pm 1.0$ & $6.196^{* * *}$ \\
\hline Waking up during sleep & $3.1 \pm 1.1$ & $3.2 \pm 1.0$ & $3.4 \pm 1.0$ & $3.1 \pm 1.0$ & $\mathrm{NS}$ \\
\hline Early awakening & $3.1 \pm 1.1$ & $3.4 \pm 1.2$ & $3.2 \pm 1.1$ & $3.1 \pm 1.2$ & $\mathrm{NS}$ \\
\hline Sleep throughout & $3.5 \pm 1.1$ & $3.7 \pm 0.9$ & $3.6 \pm 1.0$ & $3.3 \pm 1.1$ & $3.509^{*}$ \\
\hline Sleep quality index & $3.4 \pm 0.7$ & $3.3 \pm 0.7$ & $3.3 \pm 0.7$ & $3.1 \pm 0.7$ & $4.260^{* *}$ \\
\hline Fatigue & $5.0 \pm 3.2$ & $6.5 \pm 3.2$ & $5.4 \pm 2.9$ & $5.5 \pm 2.8$ & $5.078^{* *}$ \\
\hline
\end{tabular}

Note. ${ }^{*} p<0.05,{ }^{* *} p<0.01,{ }^{* * *} p<0.001$.

Tahle 2

Quantity and quality of sleep ( $1=$ poor sleep, $5=$ no problems with sleep $)$ and fatigue ( 1 = low level of fatigue, $9=$ high level of fatigue $)$ according to working hours per week

\begin{tabular}{|c|c|c|c|c|c|}
\hline $\begin{array}{l}\text { Sleep characteristics and } \\
\text { fatigue/ number of working } \\
\text { hours/week }\end{array}$ & $\begin{array}{l}21-40 \text { hours } \\
(\mathrm{n}=144) \\
\overline{\mathbf{x}} \pm \mathrm{SD}\end{array}$ & $\begin{array}{l}\text { 41-50 hours } \\
(\mathrm{n}=276) \\
\overline{\mathbf{x}} \pm \mathrm{SD}\end{array}$ & $\begin{array}{c}\text { 51-60 hours } \\
(\mathbf{n}=199) \\
\overline{\mathbf{x}} \pm \text { SD }\end{array}$ & $\begin{array}{c}61 \text { hours } \\
(\mathrm{n}=98) \\
\overline{\mathbf{x}} \pm \mathrm{SD}\end{array}$ & $\mathbf{F}$ \\
\hline Sleep duration & $7.6 \pm 1.1$ & $7.5 \pm 1.0$ & $7.3 \pm 1.2$ & $7.1 \pm 1.5$ & $3.393 *$ \\
\hline Quality of sleep & $3.4 \pm 0.9$ & $3.5 \pm 0.8$ & $3.4 \pm 0.9$ & $3.4 \pm 1.1$ & NS \\
\hline Insufficiency of sleep & $2.7 \pm 1.3$ & $2.5 \pm 1.1$ & $2.4 \pm 1.1$ & $2.1 \pm 1.2$ & $6.520 * * *$ \\
\hline $\begin{array}{l}\text { Fatigue in the morning } \\
\text { after awakening }\end{array}$ & $2.8 \pm 0.9$ & $2.7 \pm 0.9$ & $2.6 \pm 0.9$ & $2.6 \pm 1.1$ & NS \\
\hline Ease of falling asleep & $3.4 \pm 1.1$ & $3.4 \pm 0.9$ & $3.4 \pm 1.0$ & $3.5 \pm 1.1$ & NS \\
\hline Waking up during sleep & $3.1 \pm 1.1$ & $3.2 \pm 1.0$ & $3.2 \pm 1.1$ & $3.2 \pm 1.2$ & NS \\
\hline Early awakening & $3.0 \pm 1.2$ & $3.3 \pm 1.1$ & $3.2 \pm 1.1$ & $3.2 \pm 1.2$ & NS \\
\hline Sleep throughout & $3.5 \pm 1.0$ & $3.6 \pm 1.0$ & $3.4 \pm 1.1$ & $3.5 \pm 1.1$ & NS \\
\hline Sleep quality index & $3.3 \pm 0.8$ & $3.3 \pm 0.6$ & $3.2 \pm 0.7$ & $3.2 \pm 0.8$ & NS \\
\hline Fatigue & $5.1 \pm 3.2$ & $5.2 \pm 2.9$ & $5.6 \pm 3.0$ & $6.0 \pm 3.0$ & NS \\
\hline
\end{tabular}

Note. ${ }^{*} p<0.05,{ }^{* *} p<0.01 .{ }^{* * *} p<0.001$.

\section{Discussion}

Shift work, especially night shift work, and long working hours are known to impair sleep and contribute to fatigue [1, 14, 21, 22]. Quantification of shift work and working hours of physicians is a quite difficult issue because of the great diversity of shift schedules, changing work time patterns during work experience, work on call, etc. The physicians in the studied hospitals in Sofia work mainly on rotating shifts with night work (64\%), part of them work on day shifts, but had history of night shift work. Some of the latter and the ones working on morning/afternoon shifts have 1-4 night shifts on duty monthly, and $71 \%$ of the studied physicians worked on more than 3 night shifts per month during the period of the study.

The present study has demonstrated that the higher percentage of the physicians working in Sofia hospitals had over 40 working hours per week, $38 \%$ 
Correlation between sleep characteristics and working time arrangement, number of night shifts per month, overtime and working hours per week

\begin{tabular}{|l|c|c|c|c|}
\hline \multicolumn{1}{|c|}{ Sleep characteristics } & $\begin{array}{c}\text { Type of work time } \\
\text { (day, morning/afternoon, } \\
\text { rotating, night shifts) }\end{array}$ & $\begin{array}{c}\text { Number of night } \\
\text { shifts per month }\end{array}$ & Overtime & $\begin{array}{c}\text { Working hours } \\
\text { per week }\end{array}$ \\
\hline Sleep duration & .027 & -.019 & $-.110^{* *}$ & $-.131^{* *}$ \\
\hline Quality of sleep & -.042 & $-.087^{*}$ & -.041 & -.024 \\
\hline Insufficiency of sleep & $-.133^{* *}$ & $-.141^{* * *}$ & $-.230^{* * *}$ & $-.171^{* * *}$ \\
\hline $\begin{array}{l}\text { Fatigue in the morning } \\
\text { after awakening }\end{array}$ & $-.146^{* * *}$ & $-.138^{* * *}$ & $-.237^{* * *}$ & $-.095^{*}$ \\
\hline Ease of falling asleep & $-.102^{* *}$ & $-.132^{* * *}$ & .003 & .016 \\
\hline Waking up during sleep & .045 & .011 & -.005 & .002 \\
\hline Early awakening & .056 & -.001 & .031 & .063 \\
\hline Sleep throughout & .008 & -.057 & .050 & -.042 \\
\hline Sleep quality index & $-.087^{*}$ & $-.128^{* *}$ & $-.086^{*}$ & -.047 \\
\hline
\end{tabular}

Note. ${ }^{*} p<0.05,{ }^{* *} p<0.01,{ }^{* * *} p<0.001$.

worked for 41-50 hours per week, $27 \%$ worked for 51-60 hours per week and $14 \%$ worked over 61 hours per week, adding to both sleep impairment and fatigue, especially taking in consideration work characteristics of undertaking intense, responsible and decision-making work often in a lack of time.

The sleep quality was highly significantly influenced by the night work, being the worst for physicians, working more than on 5 night shifts monthly. These data are in accordance with earlier findings [ 1 , 20,23 ], as well as the data on sleep of hospital nurses in Sofia [21]. The disturbed sleep is considered as a common pathway connecting night shift work with adverse health effects and the medium in between is the insufficient recovery [14]. We were not able to differentiate the effect of duration of night shift work, as the length of service under night shift work was parallel to age of physicians.

While the night work influenced mainly the sleep quality, the long working hours influenced the sleep duration and the subjective rating for insufficiency of sleep, in greater extend in male physicians. The fatigue increased with the longer working hours, but did not reach significance.

We consider that one limitation of the study is that it failed to quantify the number of night shifts worked by the former shift working physicians, covering day shifts

\section{References}

1. Hughes R. (2008), Patient safety and quality: An evidence-based handbook for nurses, AHRQ Publication No. 08-0043, Rockville. only during the study. A study of Bjorvatn et al [24] showed that seventy percent of nurses ( 136 women and 14 men) in an intensive care unit in Norway had poorquality sleep according to the Pittsburgh Sleep Quality Index (PSQI) with shift work including night work. But these sleep problems tended to decrease with lack of exposure and recur with re-exposure. Another study showed that the effect of shift work experience was the greatest among people in their forties and reduced as participants left shift work (i.e. when they transferred to day working or retired), suggesting that the effects of shift work did not persist people to quit once shift work [19]. Another limitation of the study is the lack of the data on the available periods for recovery and their effect on sleep and fatigue because of the complexity and differences in schedule arrangements between different hospitals and departments, as well as working at the other place by $28 \%$ of the physicians.

In conclusion, our results strongly support the suggestion that shift work with 5 and more night shifts monthly contribute to impaired quality of sleep, while long working week hours to reduced sleep duration, insufficiency of sleep and fatigue among hospital physicians. Considering the precaution principle, shift work schedules for physicians should be arranged on the bases of good practice in ergonomics, and overtime work should be avoided, if possible.

2. Zhang L., Sun D. M., Li C. B. and Tao M. F. (2016), "Influencing factors for sleep quality among shift-working nurses: across-sectional study in China using 3-factor Pittsburgh sleep quality index", Asian Nursing Research, 10 (4), 277-282, doi: 10.1016/j. 
3. Wagstaff A. S. and Sigstad Lie J. A. (2011), "Shift and night work and long working hours-a systematic review of safety implications", Scand J Work Environ Health, 37 (3), 173-185. doi:10.5271/sjweh.3146.

4. Frost P., Kolstad H. A. and Bonde J. F. (2009), "Shift work and the risk of ischemic heart disease - a systematic review of the epidemiologic evidence", Scand J Work Environ Health, 35(3), 163-179. doi:10.5271/sjweh.1319.

5. Puttonen S., Hremd M. and Hublin C. (2010) «Shift work and cardiovascular disease - pathways from circadian stress to morbidity", Scand J Work Environ Health, 36 (2), 96-108. doi:10.5271/sjweh.2894

6. Vyas M. V., Garg A. X., Iansavichus A. V., Costella J., Donner A. and Laugsand L.E., (2012) " Shift work and vascular events: systematic review and meta-analysis", BMJ, 345, e480. doi:10.1136/bmj.e4800.

7. Knutsson A. and Biggild H. (2010), "Gastrointestinal disorders among shift workers", Scand J Work Environ Health, 36 (2), 85-95. doi:10.5271/sjweh.2897.

8. Pan A., Schernhammer E. S., Sun Q., Hu F. B. (2011), "Rotating night shift work and risk of type 2 diabetes: two prospective cohort studies in women", PLoS Med, 8 (12), e1001141. doi:10.1371/journal. pmed.1001141.

9. Puttonen S., Oksanen T., Vahtera J., Pentti J., Virtanen M., Salo and P. (2010), "Is shift work a risk factor for rheumatoid arthritis? The Finnish public sector study", Ann Rheum Dis, 69 (4), 779-80. doi:10.1136/ard.2008.099184.

10. Hedstrom A. K., Akerstedt T., Hillert J., Olsson, T. and Alfredsson L. (2011), "Shift work at young age is associated with increased risk for multiple sclerosis", Annals of neurology, 70 (5), 733-41. doi: 10.1002/ana.22597.

11. Ijaz S., Verbeek J., Seidler A., Lindbohm ML., Ojajдrvi A. and Orsini, N. (2013), "Night-shift work and breast cancer - a systematic review and meta-analysis", Scand J Work Environ Health, 39 (5), 431-447. doi:10.5271/sjweh.3371.

12. Ekerstedt T., Knutsson A., Narusyte J., Svedberg P., Kecklund G. and Alexanderson K. (2015), "Night work and breast cancer in women: a Swedish cohort study", BMJ Open, 5(4), e008127. doi:10.1136/bmjopen-2015-008127.

13. Åkerstedt T. (2003), "Shift work and disturbed sleep/wakefulness", Occup Med Lond, 53, 89-94.

14. Hlrid, M. (2006), "Workhours in relation to work stress, recovery and health", Scand J Work Environ Health, 32 (6), 502-514. doi:10.5271/sjweh. 1055.
15. Pilcher J. J., Lambert B. J. and Huffcutt A. I. (2000), "Differential effects of permanent and rotating shifts on self-report sleep length: a meta-analytic review", Sleep, 23, 155-63.

16. Dembe A. E., Erickson J. B., Delbos R. G. and Banks S. M. (2005), "The impact of overtime and long work hours on occupational injuries and illness: new evidence from the United States», Occupational and Environmental Medicine, 62 (9), 588-597. doi:10.1136/ oem.2004.016667.

17. Folkard S. and Tucker P. (2003), «Shift work, safety, and productivity", Occup Med 53, (2), 95-101. doi: 10.1093/occmed/kqg047.

18. van der Hulst M. (2003), "Long workhours and health", Scand J Work Environ Health, 29 (3), 171-188. doi: $10.5271 /$ sjweh.720.

19. Yang H., Schnall P. L., Jauregui M., Su T. C. and Baker D. (2006), "Work hours and self-reported hypertension among working people in California", Hypertension 48 (4), 744-750. doi:10.1161/01. HYP.0000238327.41911.52.

20. Ferri P., Guadi M., Marcheselli L., Balduzzi S., Magnani D. and Di Lorenzo R. (2016), "The impact of shift work on the psychological and physical health of nurses in a general hospital: a comparison between rotating night shifts and day shifts», Risk Manag Healthc Policy, 9, 203-211. doi : 10.2147/RMHP.S1 15326.

21. Cekova Ir., Stoyanova R., Dimitrova Ir. and Vangelova K. ( 2008), "Sleep and fatigue in hospital physicians in relation to shift work", IEA Congress Proceedings (in print).

22. Tucker P., Folkard S., Ansiau D. and Marquiй, J-C. (2011), "The effects of age and shift work on perceived sleep problems: results from the VISAT-combined longitudinal and cross-sectional study", Journal of Occupational and Environmental Medicine, 53 (7), 794798.doi:10.1097/JOM.0b013e318221c64c.

23. Sveinsdóttir, H. (2006), "Self-assessed quality of sleep, occupational health, working environment, illness experience and job satisfaction of female nurses working different combination of shifts", Scand J Caring Sci, 20 (2), 229-237. doi:10.1111/j.1471-6712.2006.00402.x

24. Bjorvatn B., Dale S., Hogstad-Erikstein R., Fiske E., Pallesen S. and Waage S. (2012), «Self-reported sleep and health among Norwegian hospital nurses in intensive care units", Nursing in Critical Care, 17 (4), 180-188. doi:10.1111/j.1478-5153.2012.00504.x.

\section{Вангелова К., Чекова І., Аимитрова I.}

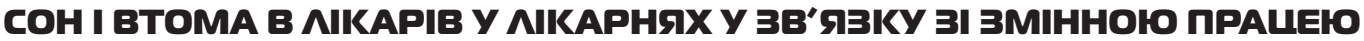

Нашіональний шентр громадської охорони здоров'я і аналізу

Bcmyn. Достатній і якісний сон має вирішальне значення для працівників, які працюють за змінним графіком, через їхній вплив на працездатність та здоров'я. 
Мета дослідження - визначити вплив нічних змін та понаднормової роботи на сон та втому лікарів у лікарнях Болгарії.

Матеріали та методи дослідження. Було проведено поперечне дослідження, яке охоплювало 719 лікарів, 429 жінок і 291 чоловіків середнього віку $(44,4 \pm 14,2)$ років) у лікарнях Софії. Анонімне анкетне опитування включало Каролінський щоденник сну, демографічну інформацію, зміни на робочому місці, робочі часи та графік змін. Статистичний аналіз проводили за допомогою SPSS.

Результати. 26 \% лікарів працювали лише в денні зміни, 55 \% від 1 до 4 ночі, і 28 \% понад 5 ночей. Велика кількість лікарів працювала понад 40 год на тиждень: 38 \% працювали 41-50 год на тиждень, 27 \% - 51-60 год і 14 \% - 61 год. Якість сну, яку оцінювали за індексом SQI, була гіршою зі збільшенням числа нічних змін $(\mathrm{F}=4,260, \mathrm{p}=0,01)$, тривалістю сну та недостатністю сну зі збільшенням робочого тижня.

Висновки. Змінна праця зі збільшенням нічних змін щомісячно та понаднормових годин на тиждень сприяла погіршенню сну в досліджуваній групі лікарів. Погіршення сну було більш очевидним у зв'язку зі збільшенням кількості нічних змін.

Ключові слова: нічні зміни, робота поза нормою, індекс якості сну

\section{Вангелова К., Чекова И., Аимитрова И. \\ СОН И УСТАЛОСТЬ У ВРАЧЕЙ В БОАЬНИШАХ В ЗАВИСИМОСТИ ОТ СMEHНОГО TPYАA}

Нашиональный шентр обшественного здравоохранения и анализа

Вступление. Достаточный и качественный сон имеет решающее значение для работников сменного труда из-за его последствий для производительности и здоровья.

Цель исследования - отследить влияние ночных смен и сверхурочной работы на сон и усталость у врачей больниц в Болгарии.

Материалы и методы исследования. Проведено поперечное исследование, которое включало 719 врачей, 429 женщин и 291 мужчину, среднего возраста $(44,4 \pm 14,2)$ года) в больницах Софии. Анонимный опросник включал Каролинский дневник сна, демографическую информацию, перемены места работы, рабочее время и сменный график. Статистический анализ проводили с помощью SPSS.

Результаты. $26 \%$ врачей работали только в дневные смены, 55 \% имели от одной до четырех ночных смен и $28 \%$ более 5 ночных смен. Большое количество врачей работало более 40 ч в неделю, а именно: $38 \%$ работали 41-50 ч в неделю, $27 \%$ - 51-60 часов и $14 \%>61$ ч. Качество сна, оцененное по индексу SQI, было хуже с увеличением числа ночных смен ( $\mathrm{F}=4,260, \mathrm{p}=0,01)$, продолжительностью сна и недостаточностью сна, с увеличением продолжительности работы в неделю.

Bыводы. Работа по сменам с большим количеством ночных смен ежемесячно и в сверхурочное время в неделю способствовали нарушению сна в исследованной группе врачей. Нарушение сна было более очевидным с увеличением числа ночных смен.

Ключевые слова: ночные смены, сверхурочное время, индекс качества сна

ORCID ID of co-authors and their contribution in preparation and writing of the paper:

Vangelova $K$. K. defining the purpose and design of the study, analyzing the results received, formulation of the conclusions, design and writing of the article;

Cekova I. V. conducting the study, review of literature on the paper subject, statistical processing, analysis of the data received;

Dimitrova I. D. conducting the study, review of literature on the paper subject, statistical processing, analysis of the data received.

Information on the research funding source. The research was funded by the National Center of Public Health and Analyses under topic 39 «Health surveillance in health care sector» of the National Programme on Safety and Health at Work, 2018-2020.

Надійшла: 14 серпня 2018 р.

Контактна особа: Вангелова К., Національний центр громадської охорони здоров'я і аналізу, Софія 1413, Болгарія. Електронна пошта: k.vangelova@ncpha.government.bg 